\title{
Medico-geographical problems of Bulgaria In the conditions of the coronavirus pandemic
}

\section{Problemas médico-geográficos de Bulgaria en las condiciones de la pandemia de coronavirus}

\author{
DOI: $10.46932 / \mathrm{sfjdv2n3-079}$
}

Received in: May 1st, 2021

Accepted in: Jun 30th, 2021

\author{
Neli Veselinova \\ Ch. Assistant, $\mathrm{PhD}$ \\ Sofia University "St. K1. Ohridski" \\ Department of Social and Economic Geography \\ Faculty of Geology and Geography \\ Tsar Osvoboditel blv № 15, Sofia, Bulgaria \\ E-mail: n_veselinova@mail.bg
}

\begin{abstract}
In 2021, it would be appropriate for the Bulgarian society to outline the first conclusions about the new conditions, due to the pandemic of coronavirus - COVID - 19 is not necessary to prove the need for an analysis to be made by medical geography. In this endeavor, Bulgarian medical geography must take on its responsibility, and this understanding is leading to the writing of this article.
\end{abstract}

Keywords: Medical geography, pandemic, coronavirus, Bulgaria, geography, medicine

\section{RESUMEN}

En 2021, sería conveniente que la sociedad búlgara esbozara las primeras conclusiones sobre las nuevas condiciones, debido a la pandemia de coronavirus - COVID - 19 no es necesario demostrar la necesidad de un análisis que debe hacer la geografía médica. En este empeño, la geografía médica búlgara debe asumir su responsabilidad, y esta comprensión es la que lleva a la redacción de este artículo.

Palabras clave: Geografía médica, pandemia, coronavirus, Bulgaria, geografía, medicina

\section{INTRODUCTION}

At the beginning, it is important to note that from a geographical point of view, the indisputable current medical crisis is not a surprise for Bulgaria.

The excuse that the coronavirus surprised the whole world and no one was prepared for it is true. The analysts, who claim this, whether they are journalists, politicians, medics, or other professionals, have a certain right. Even the term coronavirus was unknown to the general public in Bulgaria.

The unprecedented global scale of the problem, which surpassed any natural and social disasters such as epidemics or wars of the past, should not hide the fact that the new situation is mixed with accumulated long-term geographical problems of Bulgarian medicine and health. 
As a result of the measures, which were taken, the Bulgarian society was left with the impression that the responsible individuals and politicians have no understanding of the future. They often copy the positive foreign experience and Bulgaria did not show an internationally accepted and popularized example. In the period 2020 - 2021, the public attention and opinion were concentrated with daily press conferences of the operational headquarters, the time of the media was filled with monotonous discussions, measures were taken after the events, state orders and legislation were often changed.

\section{MATERIALS AND METHODS}

The structure of the proposed article includes an introduction, methods and methodology, results and subsequent analysis, discussion of the conditions and measures which were proposed about the coronacrisis and conclusion.

The object of study is the crisis in which Bulgarian society is without this crisis to be officially recognized, and the subject of study are the problems arising from this crisis.

The main goal of this paper is to analyze the current health organization and situation in Bulgaria and to prove that there are many serious medical and geographical problems in the country, which are not pointed.

The following tasks are set: determining the time range of the study, summarizing the results and analyzing the situation.

The information was obtained by various methods. The choice of a specific method depends on different factors, the most important of which are: duration of the study, available financial resources and others. The main methods for information are a retrospective analysis, statistical-demographic method, analysis and synthesis.

The main information sources of the paper are many and they are written at the end of the study.

The limitations and problems of the study stem mainly from the lack of diverse statistics.

The study covers a short period - from early 2020 to March 2021.

Many specialist geographers, individually and in collaboration with medics, have worked on the problems of medical geography in Bulgaria. Analysis of the morbidity of the population in the territory has been made, the environmental factors that influence some diseases have been studied. Dimov and Naumov study in detail the significance of the medical-geographical assessment of the territory. According to them: "The medical-geographical assessment of the economic and economic-geographical development of Bulgaria is a priority and key task for the society. The results obtained from these interdisciplinary studies have not only methodological but also applied significance. ”(2001). 
In Bulgaria, the reality shows that medics are particularly interested in medical geography and work on it, without mentioning that it is medical geography. From the medical scientists, Naumov wrote a scientific book - "Medical Geography of Bulgaria" (2004), and from the geographical scientists Veselinova - "Medical Geography - achievements and expectation" (2021).

\section{RESULTS AND DISCUSSION}

After the beginning of the pandemic in 2020, the division among the medics was a surprise for Bulgarian society. The lack of consensus among them is a reflection of the low professionalism among the Bulgarian social elite. The professional qualifications of the managers and the experts are not close to the specific problem, as in many other areas of Bulgarian society.

Bulgarian healthcare, medicine and their geographical organization are in deep crisis. This is a consequence of the weak medical geography, of the mutual misunderstanding and even ignorance between geographers and medics, of the mentioned insufficient professional competence among the leading personalities and institutions. Petrova and co-authors (2014) believe that: "A comprehensive understanding of health means that all systems and structures that manage social and economic conditions and the physical environment must take into account the possible consequences of their activities in terms of their impact on individual and collective health."

The mistake of geographers, on the other hand, is in the continuing resource orientation of natural and economic, and in recent decades the political and humanitarian geography that seeks one day public popularity. Health has not yet established itself as a leading geographical theme. Specialized geographical publications are few. Due to its thematic backwardness, medical geography began its development late and only in the education of geographers, but without providing graduates with specific employment.

The low health culture that we see on various occasions is also due to the Bulgarian school. Geography is losing positions in school, medical geography is outside the textbook, but it could provide many opportunities for practical geography. We will point out a few specific examples that directly affect the medico-geographical problems of Bulgaria. They have become even more visible as a result of the pandemic.

1. The first serious problem is related to pharmacies, which are part of healthcare and medical care. Geographically, the state has completely abandoned pharmacies and their location is completely free, chaotic, according to the laws of trade and consumption. State pharmacies are missing, even as a model. The geography of pharmacies depends on the geography of the population and its purchasing power. According to the register of pharmacies maintained by the Bulgarian Drug Agency, there are 3,814 pharmacies in the country. There is only one 
pharmacy in 37 municipalities. There are 3 or fewer pharmacies in 106 municipalities in the country. There is not a single pharmacy in 17 municipalities in the country ${ }^{1}$. The lack of geographical state standards and the requirements for commercial profit distribute pharmacies and pharmacists extremely unevenly throughout the country. There are municipalities without a pharmacy, and in Sofia, there is a street with 4 pharmacies 100 meters away, one of which is open 24 hours a day. In the capital, where $19 \%$ of the country's population lives, there are 1/3 of all pharmacies. At the same time, 11 of 27 district centers do not have a 24-hour pharmacy. The current Northwestern Statistical Region has only one 24-hour pharmacy in the city of Pleven! Although for the state, the sale of medicines is not much different from the sale of other goods, our opinion is that mandatory municipal state standards are needed, among which is the existence of at least one pharmacy with 24-hour working hours in each municipality. If free trade competition does not allow it, then the state must create or facilitate the existence of sheltered pharmacies similar to sheltered schools. Although and this is not enough for the population of small municipalities. There is no geographical connection between pharmacies and GP practices. The geography of their activity is as chaotic as the territorial location of pharmacies. In large cities, there is competition between GPs for patients, but in small remote settlements, there are no GPs. They are in their practices in the central settlements and they do not have the physical ability to serve their potential patients. Another problem is connected with modern e-prescriptions. Are e-prescriptions and other modern elements of healthcare based on the educational and physical capabilities of the elderly, the sick and a significant part of the minority population?

2. The second problem is related to emergency medical care. The geographical organization of emergency care is an eternal problem that cannot be solved. According to the statistical point of view, it should be the opposite - population and settlements which are served by emergency medical care are declining, so this care must be able to cover the whole territory and population. The problems of emergency medical care are known and they are mostly geographical. Till now geography has not been involved in solving them, because, as a science, it is unknown to Bulgarian politicians. The most serious confirmation of our statement is the long-term creation of the Bulgarian National Health Card. The problem here is that medicine is not an economy, no matter how much the Bulgarian public administration tries to prove the opposite. The attempts to identify emergency centers were very interesting. Maps were made, distances were

\footnotetext{
${ }^{1}$ http://www.265obshtini.bg/map/39
} 
measured on a map, and average speeds were calculated. It was paid an attention to the deteriorating infrastructure in the country and the geographical features.

3. The third very serious problem is with the geography of hospitals. According to Carlos RiosCampos et al. (2021): "Although the focus of tackling the direct impact of COVID-19 is important, in many healthcare settings, it is important to maintain core and critical clinical service (Carlos Rios-Campos et al. (2021); Ting, Carin, Dzau, et al., 2020)" In the geographical organization of hospitals in Bulgaria, the liberal understanding that hospitals are commercial companies and must have a monetary profit intervenes again. For this reason, we have two geographical types of hospitals - public and private. In our case, we do not comment on the ownership, but we would like to commend the principles of their location. Public hospitals are inherited from the past and each of them has its history. There are not new state hospitals in Bulgaria, especially as a location. Each of them is built and works at a different time. There is not even a children's hospital yet! Today, the hospital's transport geographical position is usually completely different and, as a rule, is aggravated. The hospital was usually in the center, it was provided with transport in the past. Today, the city has expanded and access to the central hospitals is difficult, especially for ambulances. Helicopter pads are few. For example - the UNI HOSPITAL in the town of Panagyurishte has a helicopter pad on the ground, but it is an example of an exception. A complex problem is the regionalization of hospital activities, especially in harmonization with the Bulgarian legislation. After 1989 and until the coronacrisis, Bulgarian society was convinced by the politicians how many hospitals there were in Bulgaria and how many of them were not necessary. We were constantly offered the leading foreign examples with a small number of hospitals. Maybe it is time to relieve the redundant, especially the small municipal, hospitals? In a highly centralized state, like Bulgaria, a very important role began to have the district hospitals. The main problem is the regionalization of the influence of each hospital, except the only ones with specialization. Most municipal hospitals are in the former district centers and they copy the administrativeterritorial structure of the country. The closure of various medical practices, along with the closure of schools, has been a major state reason for migration to major cities and, in recent decades, to leave the country.

4. The next problem is related to polyclinics and the role of the Diagnostic and Consulting Centers. Before 1989, the birth centers in the small settlements were closed, later - part of the resort polyclinics was closed too. The Diagnostic and Consulting Centers are the polyclinics known from the past. They are the intermediate link between the citizens and the hospitals, 
they carry out the pre-hospital medical activity. The geographical problem with the Diagnostic and Consulting Centers is again in the center-periphery model. Especially when the hospital and the Diagnostic and Consulting Center are in the central settlement, the other settlements of the municipality with their population are a few hours away from it and transport costs are expensive for the retired population. The limited capabilities of GPs cannot provide the necessary medical care. Usually, the GP's practice is in the central settlement, but he/she has to service several settlements and population at considerable distances from the central settlement. The insufficient number and capacity of Bulgarian medicine could be seen in the big cities, especially during epidemics. It would be better for citizens to have numerous and well-equipped diagnostic and consultation centers, for example with laboratories, pharmacies and parking centers. The latter also applies to city hospitals. We would like to add the problem with open/working hours in the hospitals. Everyone who needs to visit medicine doctors has to be absent from work. This must be changed.

5. Private medical practices. This novelty in our post socialist society has become a symbol of the growing division between the few rich and the many poor Bulgarian citizens. Ginny's ratio, which measures this difference, continues to grow. The differences in our country are still too large than in developed countries - while the American and Western European poor population have access to quality medicine, in Bulgaria, this is not the case.

The basis of private medical practice is entirely in financial profits. Central and local governments and citizens must rely on both private and public medicine. The state subsidies are the same for both - the state and the private practices, but while state medicine is connected with the administrative-territorial structure of the country, the private one is entirely on a business territorial basis. That means concentration in big cities and resorts where there is a guaranteed practice. It is worst when in a village there is duplication between public and private practice. Citizens rely on public state medicine, while medical professionals are looking for private practice due to higher pay. Almost all doctors work in their spare time in second and third place in the private sector. The private sector does not support the state because it chooses only well-paid practices. Instead of supporting and supplementing state medicine territorially, private medicine sharpens the territorial differences.

\section{CONCLUSION}

All critical features and conditions were seen in the coronavirus crisis. Although the legislation provides for a geographical response, in reality, the government did not comply with the law and organized 
headquarters for management and information itself. There are no decisions about the crisis at the regional and local levels in the country. Then, why are there the relevant administrative units in the country?

More than a year has passed since the appearance of the coronavirus, but there is no clear geographical organization about its removal. A typical example of managerial geographical chaos in Bulgaria is the bureaucratic decision taken for the distribution of vaccines. It was hasty, incompetent, unproven by practice, subjective. There are serious problems with the lack of certainty and with widespread rumors among the population, to which no clear answers have been given. 


\section{REFERENCES}

1. Ангелова, М. (2008) „Образцово село“. Модернизационният проект за селото в България (1937-1944 г.), Бл.

Angelova, M. (2008) "Model Village". The modernization project for the village in Bulgaria (1937-1944), B1.

2. Веселинова, Н. (2012) Проблеми на регионалната организация на спешната медицинска помощ на територията на Софийска област. Сп. Управление и образование, т. 8, Кн. 3, Б.

Veselinova, N. (2012) Problems of the regional organization of emergency medical care on the territory of Sofia district. Management and Education, vol. 8, Book. 3, B. <http://www.conferenceburgas.com/volumes_mae.html $\geq(18.01 .2021$ г.; 19:15)

3. Веселинова, Н. (2019). Консумацията на алкохол и алкохолизмът в България. Eastern academic journal, vol:3

Veselinova, N. (2019). Alcohol consumption and alcoholism in Bulgaria. Eastern academic journal, vol: $3<$ https://Www.e-acadjournal.org/article-19-3-7.html> (10.12.2020 г.; 07:09)

4. Веселинова, Н. (2020) Онкогеографски изследвания и проблеми в България. Knowledge International journal, Knowledge for sustainability, $<$ https://ikm.mk/ojs/index.php/KIJ/issue/archive $\geq$

Veselinova, N. (2020) Oncogeographic research and problems in Bulgaria. Knowledge International journal, Knowledge for sustainability, Vol 41, <https://ikm.mk/ojs/index.php/KIJ/issue/archive > (10.12.2020 г.; 11:39)

5. Веселинова, Н. (2021) Медицинската география - постижения и надежди. Парадигма, С. Veselinova, N. (2021) Medical geography - achievements and expectation. Paradigma, S.

6. Грънчарова, Г., С. Александрова-Янкуловска. (2018) Социална медицина. Шесто издание, ИЦ МУ-Плевен, Пл.

Grancharova, G., S. Alexandrova-Yankulovska. (2018) Social Medicine. Sixth edition, Pleven

7. Давидова, В. (1956) История на здравеопазването в България (Очерци). ДИ Наука и изкуство, С.

Davidova, V. (1956) History of Healthcare in Bulgaria (Essays). Science and Art, S.

8. Димов, Н., Й. Наумов. (2001) Проблеми в икономгеографското развитие на България и тяхната медико-географска оценка. Научни доклади по медицинска география, Съюз на научните медицински дружества в България, Българско дружество по медицинска география, С.

Dimov, N., J. Naumov. (2001) Problems in the economic-geographical development of Bulgaria and their medical-geographical assessment. Scientific reports in medical geography, Union of Scientific Medical Societies in Bulgaria, Bulgarian Society of Medical Geography, S.

9. Медицинска география на България, Част 1, Под редакцията на проф. д-р Йордан Михайлов Наумов, Българско дружество по медицинска география, Издателство на Съюза на учените в България, С.

Medical Geography of Bulgaria, Part 1, Edited by Prof. Dr. Yordan Mihaylov Naumov, Bulgarian Society of Medical Geography, Publishing House of the Union of Scientists in Bulgaria, S. 
10. Петрова, Зл., С. Генев, Н. Енчев, А. Воденичарова. (2014) Глосариум на най-често използваните термини и определения в организацията и управлението на здравеопазването. Изд. Еко Ринг, С.

Petrova, Zl., S. Genev, N. Enchev, A. Vodenicharova. (2014) Glossary of the most commonly used terms and definitions in the organization and management of health care. Ed. Eco Ring, S.

11. Петрова, Зл., Т. Черкезов (2017) Здравна политика. Управление на ресурсите и качеството на медицинските дейности. Сб. Лекции, Изд. „Таурус Адвертайзинг“ЕООД, МУ - София

Petrova, Zl., Т. Cherkezov (2017) Health policy. Management of resources and quality of medical activities. Lectures, Taurus Advertising EOOD, MU - Sofia

12. Попов, Б. (2018) Храни, хранене и здраве. Хигиена, хранене и професионални болести, Учебник за студенти по медицина и общопрактикуващи лекари, Под редакцията на проф. д-р Божидар Попов, дмн, Трето издание, С.

Popov, B. (2018) Food, nutrition and health. Hygiene, nutrition and occupational diseases, Textbook for medical students and general practitioners, Edited by Prof. Dr. Bozhidar Popov, MD, Third Edition, S.

13. Семенова 3. Ан., Чистобаев Ан. Ив. (2015) Медицинская география и здоровье населения. Эволюция знания, Изд. Европейский Дом

Semenova Z. An., Chistobaev An. Yv. (2015) Medical geography and public health. Evolution of Knowledge, Ed. European House

14. Симеонов, Д. (2014) География на общественото здраве в България. Социални аспекти Варна: Изд. „СТИКЕРИ-БЕ”.

Simeonov, D. (2014) Geography of public health in Bulgaria. Social aspects - Varna: Ed. "STICKERSBE".

15. Barrett, F. A. A medical geography anniversary. <https://pubmed.ncbi.nlm.nih.gov/8211285/> (07.09.2020 г.; 16:44 ч.)

16. Boyadzhiev, V., N. Veselinova (2014) European and Balkan Ruralism. Differences in Theory and Practice. Journal of Settlements and Spatial Planning, http://geografie.ubbcluj.ro/ccau/jssp/arhiva_si4_2015/08JSSPSI042015.pdf (18.01.2021 г.; 09:04)

17. Carlos Rios-Campos, Pilar Rios Campos, Freddy Camacho Delgado, Italo , Maldonado Ramírez, Juan Avalos Hubeck, Cristian Jurado Fernández, Yajaira, Carrasco Vega, Mélida Campoverde Méndez (2021) Covid-19 and Universities in Latin America. South Florida Journal of Development, Miami, v.2, n.1, p.577-585, jan./feb.2021.ISSN 2675-5459, DOI:10.46932/sfjdv2n1-041

18. Garrison, F. H. (1932) Medical geography and geographic medicine. Bulletin of the New York Academy of medicine, Voll VIII, № 10, <https://www.ncbi.nlm.nih.gov/pmc/articles/PMC2096225/ $\geq$ (21.11. 2020 г.; 10:06 ч.)

19. Meade, M., M. Emch. (2010) Medical geography. Third edition. The Guilford press. New York, London.

20. <http://www.mh.government.bg/bg/informaciya-za-grazhdani/zdravosloven-nachin-na-zhivot/_> (01.06.2020 г.; 14:22 ч.)

21. WwW.nsi.bg (26.02.2021 г.; 12:57 ч.) 
22. http://www.265obshtini.bg/map/39 (11.05.2021 г.; 13:23 ч.)

23. Meade, M., M. Emch. (2010) Medical geography. Third edition. The Guilford press. New York, London.

24. Ting, D.S.W., Carin, L., Dzau, V. et al. Digital technology and COVID-19. Nat Med 26, 459-461 (2020). https://doi.org/10.1038/s41591-020-0824-5

25. <http://www.mh.government.bg/bg/informaciya-za-grazhdani/zdravosloven-nachin-na-zhivot/ > (01.06.2020; 14:22 ч.)

26. www.nsi.bg $(26.02 .2021 ; 12: 57$ ч.)

27. http://www.265obshtini.bg/map/39 (11.05.2021; 13:23 ч.) 